outside India, of Europe and Australia. Plants of Africa and America are far less perfectly represented. The Herbarium is an essential adjunct to a botanical garden of this standard.

Introduction of quinine, rubber, ipecacuanha, various timber trees, fibre- and oil-yielding plants and other plants of great economic value is mainly due to exploration by the scientific officers of the Garden. Almost all the road-side trees and ornamental garden plants now found widely growing throughout India and Burma were first acclimatized in this Royal Botanic Garden. They were then distributed all over India and abroad. Of recent introduction is the tung oil tree, which is a source of considerable revenue in China. Experiments at this Garden indicate possibilities of cultivation of tung oil in suitable areas of Bengal in the drier lower ranges of the Himalayas at 2,000$5,000 \mathrm{ft}$. There is no reason why India should not be made self-supporting with regard to the supply of this oil, so useful for various purposes. The Garden distributes seeds to various parts of India.

The garden roads were never intended for the heavy traffic that daily passes over them. In this sense the Calcutta Gardens must be unique. In most Gardens of similar dimensions and with similar objects the visitor passes on foot; the restrictions placed upon him read very much alike wherever one goes. Custom and long precedent have allowed greater latitude to the visitor to Sibpur. Except in some of the nursery plant houses he can wander where he likes; he picnics anywhere and he even lights fires in approved spots when he wishes to cook his food. It is all to the benefit of the Garden, in that greater public enjoyment and therefore support is ensured, and on the whole it must be said advantage is not taken of the latitude allowed.

\title{
OBITUARIES
}

\section{Mr. H. J. Carter}

$\mathrm{B}$ $Y$ the death of Herbert James Carter on April 16, Australia has lost one who had taken a prominent part in both educational and scientific affairs. He was born at Marlborough, Wilts., on April 23, 1858, the son of James Carter, and was educated at Aldenham School and the University of Cambridge, where he was a scholar of Jesus College. He was a mathematics master at Sydney Grammar School during 1881-1901 and was principal of Ascham Girls School from then until 1914. He was president of the Linnean Society of New South Wales during $1925-26$, and a member of its Council from 1920 until 1939; also a fellow of the Royal Entomological Society of London. For many years he was honorary entomologist to the Australian Museum. He was science editor of the "Encyclopædia of Australia" published in 1926, and author of "Gulliver in the Bush" in which he related many of his experiences in pursuit of his scientific work.

Carter's special work was with the Australian Coleoptera, especially the families Tenebrionidæ, Buprestidæ, Cistelidæ, and Dryopidæ. In addition to descriptions of large numbers of new species, he paid particular attention to matters of synonymy, and published a number of check-lists of the families, and revisions of the Australian species of various genera. He did not shirk the drudgery of the work on synonymy, but often deplored the practice of some European colleagues who, on what he con. sidered inadequate evidence, described large numbers of Australian species as new, and so added to the difficulties of Australian coleopterists.

His papers appear in a number of scientific journals from 1905 onwards, chiefly those of the Linnean Society of New South Wales, the Royal Zoological
Society of New South Wales, and the Royal Society of South Australia. His last completed work was a short note on Dryopidæ, handed to the Linnean Society of New South Wales only a few days before his death, with the comment that he found such small objects trying to his sight and that this would probably be his last contribution on the family. His fine collection of Australian Coleoptera, including many types, will go to the Division of Economic Entomology of the Council for Scientific and Industrial Research at Canberra. A charming personality, he left a host of friends in his scientific colleagues and in his former pupils now scattered throughout Australia.

\section{Prof. C. L. Boulenger}

Prof. Charles L. Boulenger, who died on May 21, aged fifty-five, will be remembered as a successful professor, an authority on freshwater medusæ and the trainer in helminthology of a large band of biologists who were scattered through the East for disease diagnosis in the War of 1914-18.

His father was G. A. Boulenger, F.R.S., a Belgian who became a great authority on reptiles and fish at the British Museum (Natural History). The son was a scholar of St. Paul's School and entered King's College, Cambridge, in 1903 as Lawrence Saunders scholar. $\mathrm{He}$ obtained first classes in the Natural Sciences Tripos and in 1906-7 occupied his University's table at the Stazione Zoologica, Naples, for the study of medusæ. He then visited Birket el Qurun (the remains of Lake Moeris) to investigate its medusa, discovering that its stinging cells are formed in the endoderm of the manubrium and in the ectoderm of the swellings at the bases of the tentacles 